\title{
The Paradise Concept and Discourse According to Mufassir Fakhr Al-Din Al-Razi
}

Mohd Manawi Mohd Akib, Ahmad Fakhrurrazi Mohammed, Latifah Abdul Majid, Hamdi Ishak, Sharifah Basirah Syed Muhsin and Mohd Syukri Zainal Abidin

To Link this Article: http://dx.doi.org/10.6007/IJARBSS/v12-i1/11891

DOI:10.6007/IJARBSS/v12-i1/11891

Received: 08 November 2021, Revised: 16 December 2021, Accepted: 29 December 2021

Published Online: 17 January 2022

In-Text Citation: (Akib et al., 2022)

To Cite this Article: Akib, M. M. M., Mohammed, A. F., Majid, L. A., Ishak, H., Muhsin, S. B. S., \& Abidin, M. S. Z. (2022). The Paradise Concept and Discourse According to Mufassir Fakhr Al-Din Al-Razi. International Journal of Academic Research in Business and Social Sciences, 12(1), 690 -701.

Copyright: @ 2022 The Author(s)

Published by Human Resource Management Academic Research Society (www.hrmars.com)

This article is published under the Creative Commons Attribution (CC BY 4.0) license. Anyone may reproduce, distribute, translate and create derivative works of this article (for both commercial and non0-commercial purposes), subject to full attribution to the original publication and authors. The full terms of this license may be seen

at: http://creativecommons.org/licences/by/4.0/legalcode

Vol. 12, No. 1, 2022, Pg. $690-701$

Full Terms \& Conditions of access and use can be found at http://hrmars.com/index.php/pages/detail/publication-ethics 


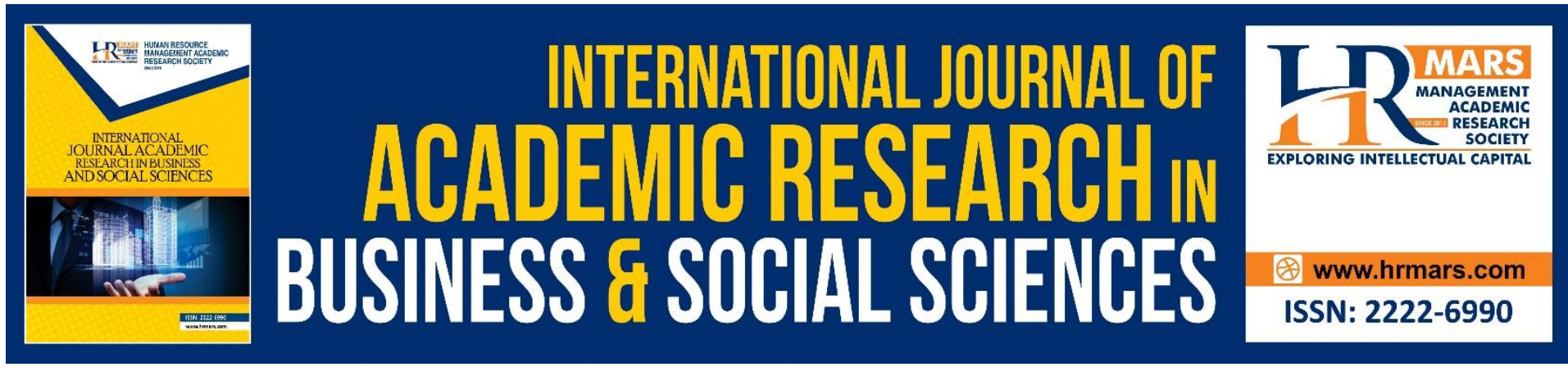

\title{
The Paradise Concept and Discourse According to Mufassir Fakhr Al-Din Al-Razi
}

\author{
Mohd Manawi Mohd Akib ${ }^{1}$, Ahmad Fakhrurrazi Mohammed ${ }^{1}$, \\ Latifah Abdul Majid ${ }^{1}$, Hamdi Ishak ${ }^{1}$, Sharifah Basirah Syed \\ Muhsin ${ }^{2}$ and Mohd Syukri Zainal Abidin ${ }^{2}$ \\ ${ }^{1}$ Research Centre for Quran and Sunnah, Faculty of Islamic Studies, Universiti Kebangsaan \\ Malaysia, UKM, ${ }^{2}$ Department of Aqidah and Islamic Thought, Academy of Islamic Studies, \\ University Malaya, UM. \\ Email:manawi@ukm.edu.my
}

\begin{abstract}
The fundamental issue in Islam that has to be stressed is the topic of faith. Some streams or sects dispute this topic using the arguments of naqal (revelation), 'aql (reason), and the way to comprehend the unique Quranic verses. Among them are the Ahl Sunnah wal Jamaah sects of Ash'arites, Mu'tazilites, and others. Among the topics covered are divinity, prophethood, and sam'iyyat, which are supernatural elements that every Muslim must be aware of and believe in. Thus, this study will address one of the aspects of sam'iyyat that is concerned with the subject of paradise according to Imam Fakhr al-Din al-Razi, an important Ash'arite figure, based on his interpretation in his tafsir work, Mafatih al-Ghayb. Views on the issue from numerous different exegetes will also be discussed as a comparison to analyze the variances and similarities of their perspectives. In this article, certain viewpoints from other sects, especially Mu'tazilites, were also addressed to clarify the distinctions between Ash'arites. This study employed qualitative research using a content analysis approach. The data collected through a document analysis based on the problems faced and was analysed using a thematic descriptive method. The results showed that the paradise of reward for the believers has been created and it is located higher than the seventh stage of the sky. The rewards were referring to the bestowal of paradise and its enjoyments and the cause of human behavior to worship Allah Almighty, which is referred to as al-hidayah. The dwellers of the paradise can also see Allah Almighty in the hereafter through the sixth senses which will be given by Allah Almighty for the dwellers of the paradise.
\end{abstract}

Keywords: Paradise, Al-Razi, Exegesis, Mafatih al-Ghayb, Ru'yah Allah.

\section{Introduction}

Life in the hereafter is a manifestation of faith in the unseen (sam'iyyat), which is the supernatural news conveyed by the Prophet Muhammad Peace Be Upon Him (PBUH) and the other prophets to be believed by the believers. The polytheists deny and do not believe in things such as the hereafter, resurrection, good and bad deeds, the calculation (al-hisab), the 
bridge (al-sirat) and others that have been provided by Allah Almighty for His servants in the hereafter (al-Bari, 1992).

Life in the hereafter is genuine and vital, whereas life in this world is only a platform for performing good actions that will be utilised as a supply in the hereafter. There, man will either stay a dweller of paradise or a dweller of hell. Paradise 's dwellers are those who believe and perform good actions in the earth, who are religious, honest, committed, and keep promises, among other characteristics. Allah SWT gives upon the dwellers of heaven pleasures that are incomparably different from those found on earth and are incapable of being expressed or conceived by human beings (Al-Amin, 1991).

\section{Problem Statement}

Faith in the hereafter and immortality after the resurrection is an essential thing in human life. The Qur'an often mentions the question of faith with the question of faith in Allah Almighty. It is because both issues are the main foundations that form the basis of spiritual determination. It also serves as a platform in human life to always be consistent with the primary objective in life, which is to worship Allah Almighty. Hence, to ensure this goal can be realized, the person must be studying the ways and guidelines of life that have been arranged by the scholars based on the guidelines of Islam (Rani, 2005). One's faith is useless without these two foundations. It will cause all the elements of goodness to disappear and become a weak human being in Islam because it cannot benefit society and even to the self. The two foundations are the pillars of aqeedah (strong belief in Allah) and the site of faith that will produce praiseworthy behaviour and a pure soul and prevent believers from doing bad things forbidden by religion.

Based on the above statements, the discussion about paradise and its enjoyment at present, a tabshir, draws back Allah Almighty's attention because modern human beings are too obsessed with the world and its pleasures. The question of paradise is a broad question, including the debate over paradise's names, characteristics, and inhabitants. Several articles have discussed the dwellers of the paradise, according to Fakhr al-Din al-Razi (Akib, 2013; Akib, 2012). However, the discussions were not focussing on the differences of opinion among the Ash'arites and Mu'tazilites scholars. Thus, by qualitative methods, the aims of this paper are as follows:

- Address one of the elements of sam'iyyat on the verses related to some of the issues of paradise as interpreted by Fakhr al-Din al-Razi, an important Ash'arite figure.

- Analyze the similarities and difference in opinions on the issue from a variety of exegetes as a comparison of their perspectives, especially between Ash'arites and Mu'tazilites.

\section{Research Findings}

The main issue related to the research problem presented is the community's negligence towards the two main principles of religion, notably faith and the hereafter. Thus, according to al-Razi, these findings advance the concept of paradise, which is one of the aspects in the dispute about the afterlife.

The following results are highlighted to address the issue as a result of the study:

\section{Brief Introduction of Al-Imam Fakhr Al-Din Al-Razi}

This paper will briefly discuss al-Razi's biography as it has been written precisely in the previous articles by (Akib, 2013; Akib, 2012). His name was Muhammad bin 'Umar bin al- 
Husayn bin al-Hasan al-Taymi al-Bakri al-Tabrastani al-Razi. His Laqab was Fahkr al-Din alRazi, Shaykh al-Islam, and he was also known as Ibn al-Khatib (Ibn Khallikan, 1998). His descendants continued from Saidina Abu Bakar al-Siddiq (al-Dawudi, n.d). He was born on Ramadhan $25,543 \mathrm{H}$ or $544 \mathrm{H}$ equivalent to $1148 \mathrm{AD}$ or $1149 \mathrm{AD}$ in Ray town. He later moved to Khawarizmi and Ma Wara' al-Nahr. He died on Monday, the beginning of the month of Syawal on $606 \mathrm{H}$ equivalent to March $29^{\text {th }}, 1210$ AD in the city of Hirah because he was poisoned by the Karamiah group (al-Dhahabi, 2003; al- Subki, n.d). His body was buried in Mount al-Masaqib in a village called Mudhdakhan located in the Hirah (Ibn Khallikan, 1998; al-Dawudi, n.d). Al-Razi is an expert in exegesis, kalam, fiqh, usul, a literary, a poet, and a doctor. He was a prominent scholar of his time in the knowledge of reasoning (al-ma'qul), knowledge of revelation (al-manqul), shariah, law, and physics (al-Qifti, 1903; Khalif, 1969). He is also said to be a mujaddid (the reviver or the Islamic reformer) in his generation (al-Dawudi, n.d). He studied and mastered all the knowledge disciplines during that time and produced works for each field of knowledge. He also learned and mastered Arabic and Persian well and producing works and poems in both languages (al-Dawudi, n.d; Khalif, 1969; al-Subki, n.d).

Therefore, al-Razi's view on paradise's question is part of the aqeedah debate and should be highlighted because his explanation is more comprehensive than other scholars. His analysis of the issue is found in his book of knowledge, but he discussed the question based on the Qur'anic verses in his tafsir book compared to other scholars who only discuss the question of paradise in their book of kalam.

\section{Definition of Al-Jannah}

The discussion about the definition of paradise in terms of linguistic and terminology is discussed briefly upon the matter. In terms of linguistic, the word al-jannah refers to a garden with fruitful dates and grape trees with lush leaves, twisted branches, and a shady place to anything underneath it. Besides, there are flowing rivers with a calm atmosphere. Meanwhile, any gardens that do not meet these characteristics are only referred to as al-hadiqah or al-bustan (al-Asfahani, 1992; Ibn Manzur, 1956; Ghalib, n.d; Akib, 2012; Akib, 2011).

In terms of terminology, al-Razi stated that al-jannah is a garden filled with date trees and branches trees, and the dark leaves covered everything underneath it. The Qur'an described the reward place for the mukmin (the believer) with the word jannah is because there are various enjoyments hidden in it (al-Razi, 1994; Sabiq, n.d; Cyril Glasse, 1999; Hassan, 1994; al-Shaykh, 2000). Therefore, paradise is a place for Allah Almighty's servants, those who are pleased by Him, and a place of reward for those who believe in Allah Almighty and His messengers as the most perfect, prosperous, beautiful place full of enjoyment and remain forever in the hereafter.

\section{The Polemics Discussion of Paradise}

This paper will not discuss the names, characteristics, and enjoyment of paradise as it has been discussed in previous articles (Akib, 2013; Akib, 2012; Akib, 2011). Thus, the article will focus on some of the polemics discussion of paradise from different views and opinions of a few streams of Islamic scholars, mainly from Ash'arites and Mu'tazilites. The view of al-Razi was brought to represent the views of the Ash'arites. Among the related issues presented in this paper are related to the creation of paradise, the entry of the dwellers of the paradise is by the mercy of Allah Almighty or by his deeds and will Allah Almighty can be seen in 
paradise. The debate is a discussion in this paper because it needs to be clearly understood by Muslims, especially in the Malay Archipelago to be in line with the mainstream ideology, Ahl sunnah wal jamaah.

Besides, it is hoped to highlight to the community the greatness of Allah's mercy to His servants through the debate of paradise and its enjoyments, which are not limited by any less or defects.

\subsection{Creation of Paradise}

The majority of Ahl sunnah wal jamaah's scholars including al-Razi said that paradise was created (makhluqah). They argued with a verse found in Chapter Ali 'Imran (3:133):

$$
\text { أُعِدَّتُ لِلْمُتَّقِينَ }
$$

Translation: Has been prepared for the pious.

However, the Mu'tazilites said that the verse should not be interpreted from an external point only. They asserted that the promised paradise to the believers will only be created after the Day of Judgment (al-Jabbar, 1998; al-Razi, 1994; al-Jumayli, 2005).

The Mu'tazilites had admitted two views, first: they explained about everything that exists at this moment will perish based on a verse from Chapter al-Qasas (28:88):

Translation: Everything is bound to perish except He, Himself.

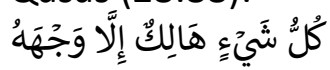

It is because the characteristics of paradise are permanent as Allah Almighty says in Chapter al-Ra'd (13:35):

Translation: .... Its fruit is lasting, and its shade...

$$
\text { أَكُلْهَا دَآَيْمَ وَظِلَّْها }
$$

Hence, they thought that paradise has not yet been created because if it had been created, it would have been destroyed and perished when the Day of Judgment occurred, and it was contrary to the verse from Chapter al-Ra'd (13:35). Second; they do not deny that the paradise provided for the angels and the believers who are still alive like the prophets, martyrs, and the others. They were created in the seventh stage of the sky but asserted that the paradise for the believers as many as seven layers of paradise and earth had not been created yet (al-Razi, 1994). They also explained that the verbs for past tense (fi'il madi) in the word u'iddat do not necessarily indicate that the action had been taken, this is because there are also verses about everything that will be happening in the hereafter were expressed with the past tense verbs. Still, it has not yet happened, for example, the inhabitants of hell calling the dwellers of the paradise and vice versa as in Chapter al-A'raf (7:44, 46 \& 50). The calling will only occur on the Day of Judgment, but the word used is for the past tense verb (al-Razi, 1994).

However, this point of view is contradicted by al-Razi, who states that the verse kull shay' halik illa wajhah is a verse that carries a general meaning, while the verses u'iddat li almuttaqin and ukulaha da'im are carrying a specific meaning. Therefore, these specific verses must come first and are excluded from the scope of the general meaning. In other words, paradise and its enjoyment have been created as a permanent place and it is a unique matter that excluded from destruction on the Day of Judgment. The word u'iddat indicates that the act has taken place or a past tense (fi'il madi). Furthermore, the statement that mentioned paradise was created in the seventh stage of the sky for the prophets and martyr was also inaccurate. Al-Razi had rejected this view by asserting that paradise was created, and it is located higher than the seventh stage of the sky. There is a hadith of the Prophet Muhammad 
PBUH that explained that the roof (saqf) of paradise is the 'Arash and it is the creation of Allah Almighty which is located after the seventh stage of the sky. Hence, it is clear that 'Arash is located after the seventh stage of the sky; therefore the paradise is also located higher than the seventh stage of the sky because the roof is 'Arash (al-Razi, 1994; al-Shaykh, 2000; al-Razi, 2000).

Based on that statement, al-Razi argued that paradise for the believers has been created and is located higher than the sky's seventh stage. This is clear with some verses of the Qur'an proving that paradise has been created, the food in it is always continuous, and many other enjoyments. Although there is a slight contradiction (tanaqud) between some of these verses on the surface, it has been discussed and then linked (tawfiq) to each other by al-Razi.

\subsection{The Dwellers of the Paradise Will Enter The Paradise With The Grace of Allah Almighty} Discussing the verse in sha' in Chapter al-Furqan (25:10):

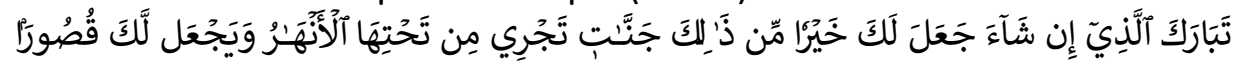

Translation: Blessed is the One Who-if He wills - can give you far better than

(all) that: gardens under which rivers flow, and palaces as well.

al-Razi and al-Baydawi argued that the verse is a reminder to human beings that they will not get the opportunity to enter paradise and its enjoyment except by the grace of Allah Almighty. He has the power to do something according to the will of Him, His grace and mercy (mashi'ati Allah wa fadlihi wa ihsanihi) without being bound by the deeds of His servants either in this world or in the hereafter (al-Razi, 1994; al-Baydawi, 1991; al-Razi, n.d).

However, if they obtain the paradise because of their rights based on deeds in the world (istihqaq), it has opened the matter to convict that Allah Almighty is ignorant. He desires His servants by stating that Allah Almighty's actions are upon the action of the creatures, while these attributes are impossible for Allah Almighty. Everything that leads to something impossible is impossible (al-Razi, 1994). Contrary to the beliefs of the Mu'tazilites where they said that the dwellers of the paradise will get the reward of paradise based on the good promise of Allah Almighty to the creatures through the reward obtained in the world (alMu'tiq, 1995).

Al-Razi also explained that paradise is obtained based on the bounty (fadl) of Allah Almighty, and not based on human deeds and attitudes toward Allah Almighty or fellow human beings (mu'amalah). He also stressed that this view is not contrary to Allah Almighty's words in Chapter Maryam (19:63) which indicated that paradise is the right and inheritance of the believers (al-Razi, 1994). He further explained that the practice is just a sign that they will get a place in paradise. In fact, a practice or good deeds occur with the will of Allah Almighty. Thus, the fact is that a believer can enter paradise by the grace and mercy of Allah Almighty and not because of their deeds only (al-Razi, 1994).

Al-Razi also said that the word bounty (fadl) found in Chapter al-Hadid (57:21):

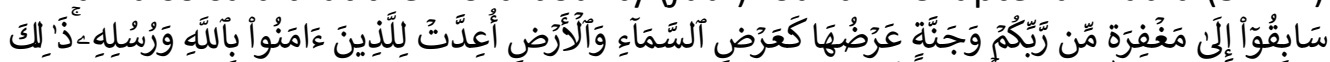

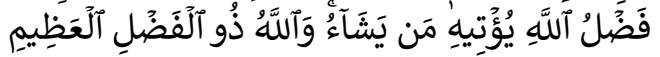

Translation: (So) compete with one another for forgiveness from your Lord and a Paradise as vast as the paradises and the earth, prepared for those who believe in Allah and His messengers. This is the favor of Allah. He grants it to whoever He wills. And Allah is the Lord of infinite bounty.

is referring to the blessings of Allah Almighty related to the things that can be done by the accountable Muslims (mukallaf) (al-umur al-lati yatamakkan al-mukallaf ma'aha) as an effort 
that is the reason for his right (istihqaq) and the mukallaf can enter the paradise through the will of Allah Almighty (al-Razi, 1994). Thus, the mentioned verse is the bounty of Allah Almighty, and is given to whomever He wills (dhalik fadl Allah yu'tihi man yasha') is specific or only indicated to those who are entitled to paradise (mashrut bi man yastahiqqah) that are the Muslims. In addition, the verse from Chapter al-Hadid (57:21) which means the human being had to compete to do good deeds to get forgiveness from Allah Almighty (sabiqu ila maghfirah min Rabbikum) and in the same chapter and verse is also specifically addressed to the believers only (al-Razi, 1994). Besides that, Allah Almighty (fadl Allah) 's bounty refers to the result of effort among the mukallaf and not based on the reward of paradise only (al-Razi, 1994).

The discussion on a verse from Chapter al-A'raf (7:43):

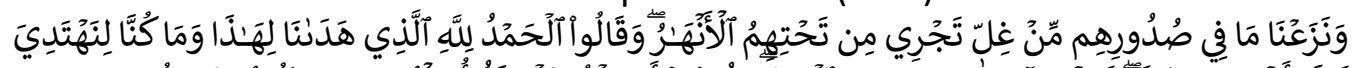

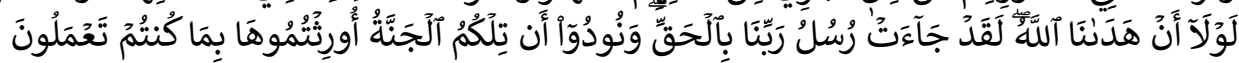

Translation: We will remove whatever bitterness they had in their hearts. Rivers will flow under their feet. And they will say, "Praise be to Allah for guiding us to this. We would have never been guided if Allah had not guided us. The messengers of our Lord had certainly come with the truth." It will be announced to them, "This is Paradise awarded to you for what you used to do."

al-Razi explained that two elements play a role in enabling a servant to obtain guidance (al-hidayah) from Allah Almighty. First; the energy that Allah Almighty gives to human beings, second; a strong impulse (al-da'iyah al-jazimah) to do something. These two elements depend on each other to enable a person to get the bounty (al-fadilah) from Allah Almighty. If only one of these elements is given to a human, it will not produce any effects (al-athar). This statement explains that action will be formed as a result of the combination of these two elements, namely the energy and strong motivation to do something. It is the cause of the guidance (al-hidayah) from Allah Almighty with His willingness and provisions (alRazi, 1994).

There is a further debate from al-Razi in the matter of human action. There were two views presented along with supporting arguments for each. First, human actions are 'not alone' (ghayr mustaqil), which is there are other factors that play a role in producing an act. Among the arguments brought by al-Razi was from Abu Hasan al-Ash'ari who said that only Allah Almighty had created that related act and power. Second, human beings are 'alone' (mustaqil) in producing an act. Among other arguments brought to support the matter was from Abu Hasan al-Basri from the Mu'tazilites who said that they made their actions a 'crucial basic thing' (bi al-darurah) which need to be known. However, al-Razi remained with his opinion which stated that human being was not alone in doing his deeds, instead, there is another factor called as a 'trigger' (al-Murajjih) which is Allah Almighty. This view was in line with the first view as the opinion of Abu Hasan al-Ash'ari (al-Razi, 1986; al-Razi, 1984; alJumayli, 2005; al-Baydawi, 1991; Subhi, 1985; Al-Bajuri, 2006; al-Attas, 2001).

The dwellers of the paradise also obtain the paradise and its enjoyment based on good promises (al-wa'd), not because of their good deeds (al-Razi, 1994; al-Razi, 1984; al-Baydawi, 1991; Ibn Kathir, 1980). The reason is that human beings must be grateful and dedicate themselves to Allah Almighty to receive abundant blessings from Allah Almighty. However, it is not the slavery and gratitude used as a ticket to oblige them to enter paradise because fulfilling the obligation does not obligate something else (al-Razi, 1994). He added that the enjoyments in paradise are continuous and have no end. If a servant confronts Allah Almighty with his deeds to get the pleasure of paradise, then indeed the enjoyments of paradise will 
be cut off and will not last when all the deeds are completed with the reward (al-Mu'tiq, 1995; al-Razi, 1994).

Thus, these were the views expressed by al-Razi, al-Baydawi, and ibn Kathir related to the matter of the dwellers of the paradise who can enter paradise only based on Allah's grace Almighty. These views are in line with Prophet Muhammad PBUH's hadith as stated by alBukhari and al-Muslim who explained that no human being can enter paradise based on his deeds, including Prophet Muhammad PBUH. In fact, they all obtain paradise based on the blessings of Allah Almighty (al-Shaykh, 2000).

From the above arguments, it is clear that the enjoyment enjoyed by the dwellers of the paradise is based on the grace and mercy of Allah Almighty. The reward refers to the bestowal of paradise and its enjoyment and the cause of human behavior to perform worship to Allah Almighty, which is referred to as al-hidayah. Their good religious practice is also an obligation that must be performed by every mukallaf as a sign of gratitude to Allah Almighty and not as a reason to get into paradise.

\subsection{The Dwellers of the paradise Able to See Allah Almighty (Ru'yah Allah)}

Among the issues that can be linked in this chapter is the matter of seeing Allah Almighty. In discussing a verse from Chapter Yunus (10:26):

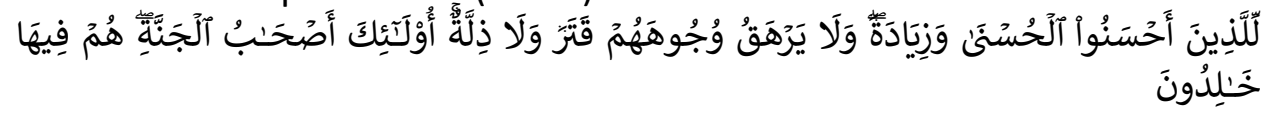

Translation: Those who do good will have the finest reward (paradise) and even more (Seeing Allah Almighty in the Hereafter). Neither gloom nor disgrace will cover their faces. It is they who will be the residents of Paradise. They will be there forever.

al-Razi, al-Baydawi, and ibn Kathir agreed with al-Tabari explaining that paradise's inhabitants can see Allah Almighty in the hereafter (al-Razi, 1994; al-Tabari, 1992; al-Baydawi, 1991; Ibn Kathir, 1980). Al-Razi brings some arguments from the point of view of naqal (revelation) and 'aql (reason) to convict the matter. From the point of view of naqal evidence, he quoted a hadith that he understood: "Indeed (meaning) al-husna is paradise, while (meaning) al-ziadah is to see Allah Almighty (al-nazr ila Allah)" (al-Razi, 1994; al-Razi, n.d; al-Razi, 1986; Al-Ash'ari, n.d; Al-Bajuri, 2006; al-Shaykh, 2000).

Based on the arguments of 'aql (reason), he explained that the word al-husna is referring to paradise with great enjoyment in it. When it was put in that way, the meaning of al-ziadah is necessarily different from paradise and all the enjoyment in it. Otherwise, the word al-ziadah is just a repetition (tikrar) only. Al- Razi asserted that every group with such a point of view would be thought that al-ziadah means seeing Allah Almighty (ru'yah Allah). Therefore, to support this view, al-Razi brought two verses of the Qur'an, first; Chapter al-Qiyamah (75:22-23) which means "The faces (of the believers) on that day will be radiant. Looking at their Lord" and according to him again, the majority scholars of Ahl sunnah wal jamaah adhered to this verse in attributing that the believers can see Allah Almighty on the Day of Judgment (al-Razi, 1994; al-Razi, n.d; al-Razi, 1986). Second; Qur'anic verse from Chapter al-Insan (76:20) which means "And if you looked around, you would see (indescribable) bliss and a vast kingdom" and al- Razi also said that the word al-mulk alkabir in the verse was meaning ru'yah (al-Razi, 1994).

Discussing the verse from Chapter al-Mutaffifin (83:15) which is:

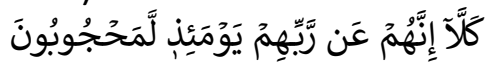


Translation: Undoubtedly, they will be sealed off from their Lord on that Day.

al-Razi explained that only the infidels will be veiled from seeing Allah Almighty on the Day of Judgment. Understanding the verse showed that the believers are not included in the meaning of the verse and can see Allah Almighty in the hereafter (al-Razi, 1994).

In addition, al-Razi also quoted the view from Darar bin 'Amru al-Kufi who said that Allah Almighty cannot be seen by the 'eyes' (al-'ain) but can be seen with the sixth senses that Allah Almighty had made on the Day of Judgment. Al-Kufi said that the verse from Chapter al-An'am (6:103) is "No vision can encompass Him, but He encompasses all vision. For He is the Most Subtle, All-Aware (No one is able to see Allah in this world, but there is extensive evidence in the Quran and the teachings of the Prophet Muhammad PBUH that the believers will be able to see their Lord on the Day of Judgment)" (la tudrikuhu al- absar wa huwa yudriku al-absar), the verse explained the specific denial towards something, that is, the denial of 'seeing' (idrak) of Allah Almighty through the 'sense of sight' (albasar). Therefore, according to him, seeing Allah Almighty without going through the 'sense of sight' (al-basar) is 'permissible' (ja'iz). This view is emphasized by him in which he said that 'the denial of a law with something, shows that a situation other than that had brought the opposite law' (takhsis al-hukm bi al-shay 'yadull' ala ann al-hal fi ghayrih bi khilafih). When it is confirmed that all the human senses that are present are not able to see Allah Almighty, then it is crucified that indeed Allah Almighty will create the sixth sense in the hereafter that with it the dwellers of the paradise can 'see Allah Almighty' (idrakuh) (al- Razi, 1994).

In contrast to the view of the Mu'tazilites, they denied that the dwellers of the paradise will be able to see Allah Almighty. They argue by saying that if Allah Almighty can be seen, then this matter has been convicted that Allah Almighty is having mass, were located and have members, while all these things are impossible for Allah Almighty (al-Jabbar, 1998; al-Mu'tiq, 1995; Subhi, 1985).

Referring to the books of al-Arba'in fi Usul al-Din and al-Khamsun fi Usul alDin; among the works of kalam knowledge by al-Razi, he is consistent with the view that the dwellers of the paradise can see Allah Almighty based on 'Allah Almighty can be seen from the necessity of His Essence (Dhat)' (sihhah al-ru'yah min lawazim dhatih). In al-Arba'in, alRazi explained that 'our sect' (madhhabuna) which refers to the Ahl sunnah wal jamaah, is more inclined to the view of al-Sheikh Abu Mansur al-Maturidi who said that the validity of seeing Allah Almighty cannot be convicted or proven with logical or rational arguments, except adhering to what is stated by the Qur'an either in the form of 'comprehensible verse' (muhkamat) or 'unclear verse' (mutashabihat) and hadith (al-Razi, 1986).

Al-Razi also presented some other arguments of naqli (revelation) when discussing this matter, among them was the verse from Chapter al-Kahf (18:107 \& 110). In verse of 107, alRazi asserted that the 'paradises' (jannah) are the 'abode' (nuzula) for the believers. After entering paradise, they will be given 'honor' (al-khil'ah), and the 'highest honor' (al-khil'ah al'ulya) is 'seeing' (al-ru'yah) Allah Almighty. While in the verse of 110, al-Razi explained that the word 'meeting' (liqa') in the verse means 'whoever believes and hopes for a meeting with his Lord' (fa man kana yarju liqa'a Rabbihi ) means to see (al-ru'yah) Allah Almighty (al-Razi, n.d).

According to him, Prophet Musa or Moses begged to see God is to show that ru'yah Allah is a matter of mumkin (possible) and it is not a 'taboo' (mumtani'ah) (al-Razi, 1986; al-Razi, n.d). Similarly, the words of Allah Almighty in Chapter al-A'raf (7:143) which means 'If it remains firm in its place, only then will you see Me' (fa'in istaqarra makanahu 
fasawfa tarani). Al-Razi asserted that Allah Almighty had associated ('allaqa) ru'yah with the possible thing which is 'strengthening and determination of the mount' (istiqrar al-jabal). If the mount is strong in its place and able to be the place of tajalli for the Essence of Allah (Dhat), then Prophet Musa will be able to see Allah's face, but the mount is not able to survive and even destroyed. Similarly, in the words of Allah regarding the prohibition of infidels to enter paradise, Allah had associated ('allaqa) the prohibition with the possible thing, that is, infidels will be able to enter paradise if the camel can enter the needle hole, but such things are impossible (al-Razi, n.d; al-Razi, 1984; Al-Ash'ari, n.d). Al-Razi also asserted that 'something associated or conditional with the possible thing is possible' (al-mu'allaq 'ala mumkin, mumkin) (al-Razi, 1986; al-Razi, n.d). Based on the above arguments, it is can be concluded that Allah Almighty can be seen in the hereafter.

In contrast to al-Jubba'i who said that al-husna means the reward that is entitled to be obtained (al-thawab al-mustahaq), while al-ziadah means additional reward from Allah. This is because the Mu'tazilites think that al-ziadah should also mean 'the reward of additional enjoyment enjoyed by the dwellers of the paradise from the same category' (an takun min jins al-mazid 'alayh). While seeing Allah is not part of the same enjoyment as the category of al-husna (al-Jabbar, 1998; al-Mu'tiq, 1995). Thus, al- Razi refutes such point of view by saying that the view that mentions al-ziadah should mean 'reward of additional enjoyment' (al-mazid 'alayh) is only accepted if the maximum rate for that enjoyment is known. But it is clear that the enjoyments of paradise are always increasing, and the limits and rate of such enjoyments are unknown. It is clear that al-ziadah does not mean 'reward of additional enjoyment' (al-mazid 'alayh) but it means seeing Allah Almighty (ru'yah Allah) (alRazi, 1994; al-Razi, n.d).

Therefore, these were the arguments of al-Razi in discussing this issue and he brought evidence from the naqli (revelation) and 'aqli (reason) to prove that Allah Almighty can be seen by the dwellers of the paradise. The author finds that other commentators such as alTabari, al-Baydawi, and Ibn Kathir only put a simple argument compared to al-Razi. This clearly showed the greatness of al-Razi in presenting a clear and comprehensive argument related to an issue that is discussed.

\section{Conclusion}

Based on the above explanation, it is clear that in the understanding of Ash'arites, the paradise of reward for the believers has been created and it is located higher than the seventh stage of the sky. The enjoyment enjoyed by the dwellers of the paradise is based on the grace and mercy of Allah Almighty. The rewards were referring to the bestowal of paradise and its enjoyments and the cause of human behavior to worship Allah Almighty, which is referred to as al-hidayah. In addition, the dwellers of the paradise can also see Allah Almighty in the hereafter through the sixth senses which will be given by Allah Almighty for the dwellers of the paradise. In contrast to the dwellers of hell, they will be veiled from the matter.

This paper can help individuals grasp the concept of paradise and its enjoyment, as well as act as motivation to be more attentive in their worship. These findings can also be applied to guide future study in the fields of psychotherapy and community counselling.

\section{Acknowledgement}

This study using fund under research grant GGPM-2021-017 (Geran Galakan Penyelidik Muda) from UKM, Malaysia. 


\section{References}

Akib, M. M. M. (2012). Penghuni Syurga menurut Pandangan Fakhr al-Din al-Razi: Tumpuan Terhadap Kitab Mafatih al-Ghayb. Usuluddin Journal, No. 35, January-June. University of Malaya. 25-46.

Akib, M. M. M. (2013). Pandangan Fakhr al-Din al-Razi Mengenai Sifat-Sifat Syurga: Tumpuan Terhadap Kitab Mafatih al-Ghayb.Dimensi Islam dalam Penyelidikan Kontemporari. University of Malaya. 157-177.

Akib, M. M. M. (2011). Pemikiran Fakhr al-Din al-Razi Tentang Syurga Berdasarkan Tafsir Mafatih al-Ghayb. Master's Dissertation, University of Malaya.

Al-Amin, M. A. A. (1991), Sharh Muqaddimah Ibn Abi Zaid al-Qayrawani fi al-'Aqidah, Jeddah: Maktabah Dar al-Matbu'ah al-Hadithah.

Al-Asfahani, R. (1992). Mufradat Alfaz al-Qur'an. tahqiq: Safwan 'Adnan Dawudi, Dimashq: Dar al-Qalam.

Al-Ash'ari, A. (n.d). Al-Ibanah 'an Usul al-Diyanah, tahqiq. Fawqiyah Husin Mahmud, alQaherah: Dar al-Kitab li Taba 'wa al-Nash wa al-Tawzi'.

Al-Attas, S. M. N. (2001). Risalah Untuk Kaum Muslimin, Kuala Lumpur: ISTAC.

Al-Bajuri. (2006). Hashiyah al-Imam al-Bayjuri 'ala Jawharah al-Tawhid al-Musamma Tuhfah al-Murid' ala Jawharah al-Tawhid, tahqiq: 'Ali Jum'ah Muhammad al-Shafi'i, cet. 3, alQaherah: Dar al-Salam.

Al-Bari, F. (1992). Al-Yaum al-Akhir bayn al-Yahudiyah wa al-Masihiyah wa alIslam. ManChapter: Dar al-Wafa 'li al-Taba'ah wa al-Nashr wa al-Tawzi'.

Al-Baydawi, N. (1991). Tawali 'al-Anwar wa Matali' al-Anzar. Al-Qaherah: Maktabah alAzhariyah li al-Turath.

Al-Dawudi, M. A. (n.d). Tabaqat al-Mufassirin, j. 2, tahqiq: 'Ali Muhammad' Umar. Al-Cairo: Maktabah Wahbah.

Al-Dhahabi, M. H. (2003). Al-Tafsir wa al-Mufassirun, j. 1, c. 8, al-Cairo: Maktabah Wahbah.

Al-Jabbar, A. (1998). Al-Usul al-Khamsah. tahqiq: Faisal Badir 'Aun, Kuwait: Lajnah al-Ta'lif wa al-Ta'rib wa al-Nashr.

Al-Jumayli, H. A. (2005). Al-Imam al-Ghazali and Ara'uhu al-Kalamiyah. Beirut: Dar al-Kutub al-'Ilmiyah.

Al-Mu'tiq, A. (1995). Al-Muktazilah wa Usulihim al-Khamsah wa Mawqif ahl Sunnah Minha . Riyadh: Maktabah al-Rusyd.

Al-Qifti, J. (1903). Tarikh al-Hukama', Leipzig: Dieterich'sche Verlagsbuchhandlung.

Al-Razi, F. (n.d). Al-Masa'il al-Khamsun fi Usul al-Din, tahqiq Ahmad Hijazi al-Saqa. Qaherah: al-Maktabah al-Thaqafi.

Al-Razi, F. (1984). Muhassal Afkar al-Mutaqaddimin wa al-Muta'akhkhirin min 'Ulama' wa alHukama 'wa al-Mutakallimin . Beirut: Dar al-Kutub al-'Arabi.

Al-Razi, F. (1986). A l-Arba'in fi Usul al-Din, tahqiq Ahmad Hijazi al-Saqa, j. 2 Qaherah: Maktabah al-Kulliyat al-Azhariyah.

Al-Razi, F. (1994). Tafsir al-Fakhr al-Razi al-Mushtahar bi al-Tafsir al-Kabir wa Mafatih alGhayb. Beirut: Dar al-Fikr.

Al-Razi, F. (2000). Ma'alim Usul al-Din. tahqiq: Dr Ahmad 'Abd al-Rahim al-Sayih \& Dr Sami' Afifi Hijazi. Cairo: Markaz al-Kitab li al-Nashr.

Al-Shaykh, S. M. (2000). Mausu'ah al-Hadith al-Sharif al-Kutub al-Sittah , cet. 3, Riyadh: Dar al-Salam li al-Nashr wa al-Tawzi '.

Al-Subki, T. (n.d). Tabaqat al-Shafi'iyah al-Kubra. Egypt: Matba'ah al-Husainiyah al-Misriyah. 
Al-Tabari, J. (1992). Tafsir al-Tabari al-Musamma Jami 'al-Bayan fi Ta'wil al-Qur'an. Beirut: Dar al-Kutub al-'Ilmiyah.

Cyril, G. (1999). Ensiklopedi Islam (ringkas) Cyrill Glasse. Ghufron A. Mas'adi. c. 2. Jakarta: Fajar Interpratama Offset.

Ghalib, M. (n.d). Mafatih al-Ma'rifah, TTP Mu'assasah 'Izz al-Din li al-Taba'ah wa al-Nashr.

Hassan, A. (1994). Tabsit al-'Aqa'id al-Islamiyyah. c. 6. TTP Dar al-Tauzi 'wa al-Nashr wa alIslamiyyah.

Ibn Kathir, A. F. (1980). Al-Bidayah wa al-Nihayah, cet. 3. Beirut: Maktabah al-Ma'arif.

Ibn Khallikan. (1998). Wafayat al-A'yan wa Anba 'Anba' al-Zaman, tahqiq: Dr Yusof 'Ali Tawil \& Dr Maryam Qasim Tawil, j. 4. Beirut: Dar al-Kutub al-'Ilmiyah.

Ibn Manzur. (1956). Lisan al-'Arab, j. 13. Beirut: Dar al-Sadir.

Khalif, F. (1969). Fakhr al-Din al-Razi. Egypt: Dar al-Ma'arif.

Rani, M. Z. A. (2005). Sasterawan Sebagai Insan: Satu Penelitian Terhadap Beberapa Pandangan Sarjana. Journal of Aqidah and Islamic Thought (AFKAR), No.6, May. University of Malaya. 243-272.

Sabiq, S. (n.d). Al-Aqa'id al-Islamiyyah . Beirut: Dar al-Fikr.

Subhi, A. M. (1985). Fi 'Ilm al-Kalam Dirasah Falsafiyah li Ara' al-Firaq al-Islamiyah fi Usul alDin jild 1 al-Mu'tazilah. Beirut: Dar al-Nahdah al-'Arabiyah. 